\title{
PERAN BADAN PENGAWAS OBAT DAN MAKANAN DALAM MELINDUNGI KONSUMEN TERKAIT PEREDARAN MINUMAN TRADISIONAL LOLOH CEMCEM TANPA IZIN EDAR DI TABANAN*
}

\author{
Oleh: \\ I Made Gede Leonada** \\ Ida Ayu Sukihana** \\ Program Kekhususan Hukum Bisnis \\ Fakultas Hukum \\ Universitas Udayana
}

\begin{abstract}
Abstrak
Indonesia merupakan negara berkembang yang mana salah satu aspek yang sangat mempengaruhi perkembangannya adalah di bidang perekonomian, dalam hal ini meliputi bidang perdagangan. Konsumen yang menjadi komponen penting dalam kegiatan perdagangan ini, justru sangatlah lemah dalam perlindungan hukumnya. Konsumen sering mendapatkan akibat yang memprihatinkan dari berbagai segi, terutama dari segi kesehatan. Para konsumen merupakan golongan yang rentan dieksploitasi oleh pelaku usaha. Seiring perkembangan jaman banyak pelaku usaha yang melakukan kecurangan dengan mengedarkan produk makanan, minuman, ataupun obat-obatan. Dalam hal ini minuman tradisional loloh cemcem yang beredar tanpa memiliki izin edar menimbulkan kerugian bagi konsumen di kabupaten Tabanan.

Metode yang digunakan dalam penelitan ini adalah metode penelitian empiris, serta jenis pendekatan yang digunakan dalam penelitian ini yaitu pendekatan fakta dan pendekatan perundangundangan.

Peranan BPOM dalam melindungi konsumen terhadap peredaran minuman tradisional loloh cemcem yaitu mememberikan edukasi, komunikasi, dan informasi. Upayaupaya yang dapat dilakukan konsumen ialah penyelesaian sengketa di luar pengadilan dan penyelesaian sengketa konsumen melalui pengadilan.
\end{abstract}

Kata kunci: BPOM, konsumen, loloh cemcem.

* Jurnal ini dibuat berdasarkan ringkasan skripsi.

** Penulis Pertama dalam penulisan ini ditulis oleh I Made Gede Leonada adalah Mahasiswa Fakultas Hukum Universitas Udayana.

${ }_{* * *}$ Penulis Kedua dalam penulisan ini ditulis oleh Ida Ayu Sukihana, SH.,MH adalah Dosen Fakultas Hukum Universitas Udayana. 


\begin{abstract}
Indonesia is a developing country where one aspect that greatly influences its development is in the economic field, in this case covering the field of trade. Consumers who are an important component in this trade activity are actually very weak in their legal protection. Consumers often get alarming consequences from various aspects, especially in terms of health. Consumers are a group that is vulnerable to being exploited by business actors. Along with the development of many businesses who commit fraud by distributing food products, drinks, or drugs. In this case the traditional loloh cemcem drinks that circulate without having marketing licenses cause losses to consumers in tabanan district.

The method used in this research is empirical research methods, as well as the types of approaches used in this study, namely the fact approach and the legal approach.

$B P O M$ 's role in protecting consumers from the circulation of loloh cemcem traditional beverages is to provide education, communication and information. Up to the moment, when there are people who are out of the way and there are people who are living there.
\end{abstract}

\title{
Keywords: BPOM, consumers, loloh cemcem.
}

\section{PENDAHULUAN}

\subsection{Latar Belakang}

Indonesia sangat terkenal dengan keanekaragaman suku bangsa, adat istiadat, dan budayanya. Salah satu pulau yang sangat terkenal dengan keanekaragaman budayanya yaitu Pulau Bali, mulai dari berbagai macam keseniannya seperti seni tari, seni tabuh, ada juga upacara agama, ritual yang unik, dan sajian makanan dan minuman yang khas dari setiap daerah. Salah satunya daerah desa penglipuran, dengan minumannya yang khas yang bernama loloh cemcem, Loloh cemcem ini merupakan sejenis jamu yang kini sudah terkenal di seluruh wilayah di luar Bangli. Loloh cemcem ini juga memiliki khasiat yang baik untuk pencernaan dan menurunkan tekanan darah. Loloh Cemcem merupakan minuman tradisional yang diolah secara tradisional pula, merupakan campuran dari daun cemcem, daun kayumanis, 
daun jarak pagar, daun sirih, daun dapdap, kelapa muda, gula aren, garam dapur. Loloh ini hanya ada di Desa Penglipuran, dan merupakan minuman khas. Wisatawan yang datang ke Desa Penglipuran pasti mencoba meminumnya dan tidak jarang dijadikan oleh-oleh. Loloh ini hanya bertahan dalam lemari pendingin 2-3 hari saja.

Pembuatan loloh cemcem yang sedarhana membuat produden loloh cemcem tidak hanya di desa penglipuran saja, namun sudah menyebar di berbagai kabupaten di Bali. Banyaknya produsen loloh cemcem di Bali membuat konsumen dengan mudahnya membeli loloh cemcem yang saat ini sudah sangat mudah ditemukan di warung-warung. Konsumen adalah pengguna akhir dari suatu produk, yaitu setiap pemakaian barang dan/atau jasa yang tersedia dalam masyarakat, baik bagi kepentingan diri sendiri, keluarga, orang lain, maupun makhluk hidup lain dan tidak unduk diperdagangkan. ${ }^{1}$ Keberadaan konsumen sebagai komponen yang sangat penting, justru sangatlah lemah dalam perlindungan hukumnya. Konsumen sering pula mendapat akibat yang sangat memprihatinkan dari berbagai segi, terutama bila dilihat dari segi kesehatan yang pengaruhnya pada jasmani dan rohani seseorang. ${ }^{2}$

Rendahnya pengetahuan masyarakat mengenai mutu dan keamanan pangan menyebabkan maraknya pelanggaran terhadap hak-hak konsumen. Konsumen berhak atas kenyamanan, keamanan, dan keselamatan dalam mengkonsumsi barang dan/atau jasa, untuk memilih barang dan/atau jasa serta mendapatkan barang dan/atau jasa tersebut sesuai dengan nilai

${ }^{1}$ Munir Faudy, 2008, Pengantar Hukum Bisnis, Citra Aditya Bakti, Badung, h. 227.

2 Ahmadi Miru, 2017, Prinsip-Prinsip Perlindungan Hukum Bagi Konsumen Di Indonesia, ed.1, cet.3, Rajawali Pers, Depok, h.14. 
tukar dan kondisi serta jaminan yang dijanjikan, ha katas informasi yang benar jelas, dan jujur mengenai kondisi barang dan/atau jasa, hak utuk didengar pendapat dan keluhannya atas barang dan/atau jasa yang digunakan, hak untuk mendapatkan advokasi, perlndungan, dan upaya penyelesian sengketa perlindungan konsumen secara patut. ${ }^{3}$

Hal tersebut diperparah dengan ketidaktahuan masyarakat sebagai produsen pangan olahan dalam lingkup rumah tangga baik disengaja maupun tidak menggunakan bahan tambahan pangan tidak sesuai dengan kriteria yang telah ditentukan. Karena posisi konsumen yang lemah maka konsumen harus dilindungi oleh hukum. Salah satu sifat sekaligus tujuan hukum adalah memberikan perlindungan (pengayoman) kepada masyarakat. Pangan termasuk kebutuhan dasar terpenting dan sangat esensial dalam kehidupan manusia, disamping dua kebutuhan dasar lainnya yaitu sandang dan papan. Demikian pentingnya fungsi pangan bagi manusia, sehingga tanpa pangan manusia tidak akan dapat bertahan hidup. ${ }^{4}$ Hukum perlindungan konsumen sebagai suatu kebutuhan harus senantiasa disosialisasikan untuk memenuhi hak konsumen yakni berhak atas kenyamanan, keamanan, dan keselamatan dalam mengkonsumsi barang dan/atau jasa. Selain itu terdapat produk-produk industri rumah tangga yang tidak memiliki izin edar, sehingga tidak adanya pengujian terhadap produk tersebut.

3 A.A Gde Agung Brahmanta, 2016, "Perlindungan Hukum Bagi Konsumen Dalam Perjanjian Baku Jual Beli Perumahan Dengan Pihak Pengembang di Bali", Acta Comitas, Vol. 1 No. 02, Oktober 2016, h. 211, https://ojs.unud.ac.id/index.php/ActaComitas/article/view/24953/16186, diakses tanggal 3 Januari 2019.

4 Irna Nurhayati, 2009, "Efektifitas Pengawasan Badan Pengawas Obat dan Makanan Terhadap Peredaran Produk Pangan Olahan Impor Dalam Mewujudkan Perlindungan Konsumen”, Jurnal Ilmiah, Vol 21 nomor 2, Juni 2009, h. 17, https://jurnal.ugm.ac.id/jmh/article/view/16265, diakses tanggal 1 februari 2019 . 
Selain minimnya pengetahuan masyarakat serta sulit mengetahui produk olahan pangan yang mengandung bahan berbahaya, terdapat faktor individu konsumen sendiri yang lebih cenderung mengkonsumsi dan memilih produk olahan pangan tanpa memperhatikan kualitas dari produk olahan pangan tersebut. ${ }^{5}$ Sehingga produsen merasa aman menggunakan bahan tambahan pangan yang tidak sesuai dengan ketentuan. ${ }^{6}$

Seiring perkembangan jaman banyak pelaku usaha yang melakukan kecurangan dengan mengedarkan produk makanan, minuman, ataupun obat-obatan tanpa memiliki izin edar yang sewaktu-waktu dapat menimbulkan kerugian bagi konsumen, salah satu contohnya adalah minuman tradisional loloh cemcem. Maka dari itu dibutuhkan badan yang bertanggungjawab untuk mengawasi dan memantau peredaran produk-produk yang beredar di masyarakat.

\subsection{Rumusan Masalah}

Berdasarkan uraian latar belakang diatas, maka penulis menarik suatu permasalahan yang akan dibahas dalam penulisan jurnal ini. Adapun rumusan masalah tersebut yakni sebagai berikut:

1. Bagaimana peran BPOM dalam melindungi konsumen terkait peredaran minuman tradisional loloh cemcem yang tidak memiliki izin edar?

2. Bagaimana upaya hukum konsumen dalam hal minuman tradisional loloh cemcem yang tidak memiliki izin edar menimbulkan kerugian?

\footnotetext{
5 Badan Pengawas Obat dan Makanan, 2013, "Latar Belakang Badan Pengawas Obat dan Makanan", URL: https://www.pom.go.id/new/view/direct/background diakses tanggal 7 Oktober 2018.

6 Celina Tri Siwi Kristiyanti, 2011, Hukum Perlindungan Konsumen, Sinar Grafika, Jakarta, h. 43.
} 


\subsection{Tujuan Penulisan}

Tujuan penulisan karya ilmiah ini adalah untuk mengetahui peran BPOM dalam melindungi konsumen terkait peredaran minuman tradisional loloh cemcem yang tidak memiliki izin edar dan upaya hukum yang dapat dilakukan konsumen dalam hal minuman tradisional loloh cemcem yang tidak memiliki izin edar menimbulkan kerugian.

\section{ISI MAKALAH}

\subsection{Metode Penelitian}

Dalam penulisan karya ilmiah ini, metode penelitian yang digunakan yaitu metode empiris, jenis penelitian ini merupakan salah satu cara penelitian agar mendapatkan suatu fakta-fakta dan kebenaran yang akurat dengan membandingkan aturan yang ada dengan pelaksanaan atau kenyataan dalam masyarakat (dasollen dan dassein) yang harus digabungkan secara serasi sehingga memperoleh sistematika penelitian hukum. ${ }^{7}$ Dalam penelitian ini digunakan dua jenis pendekatan yaitu pendekatan perundang-udangan (the statue approach) dan pendengan fakta (the fact approach). ${ }^{8}$

\subsection{Hasil dan Pembahasan}

\subsubsection{Peran BPOM dalam melindungi konsumen terkait peredaran minuman tradisional loloh cemcem yang tidak memiliki izin edar?}

Sebagai bentuk keseriusan Pemerintah untuk melindungi masyarakat dari peredaran obat dan makanan yang beresiko membahayakan kesehatan konsumen. Dibentuklah lembaga

7 Philipus M. Hadjon dan Tatiek Sri Djatmiati, 2005, Argumentasi Hukum, Gadjah Mada University Press, Yogyakarta, h. 2.

8 Soerjono Soekanto, 2012, penganter penelitian hukum, Universitas Indonesia (UI-Press), Jakarta, h.51. 
Badan Pengawas Obat dan Makanan (BPOM) yang bertugas menyelenggarakan tugas pemerintahan di bidang pengawasan obat dan makanan sesuai sebagaimana diatur dalam Pasal 2 Peraturan Presiden Nomor 80 Tahun 2017 tentang Badan Pengawas Obat dan Makanan. ${ }^{9}$

Berdasarkan hasil wawancara peneliti dengan Dra.Luh Putu Withariathi.Apt (Kepala Bidang Sertifikasi dan Layanan Informasi Konsumen, BPOM Proinsi Bali) menyatakan bahwa BPOM bertanggung jawab memberikan edukasi, komunikasi, dan informasi. Edukasi yang dilakukan BPOM berupa pembinaan pelaku usaha maupun kelompok-kelompok usaha agar lebih memahami hak dan kewajibannnya, melalukan pengawasan sebelum beredar dan pengawasan selama beredar dalam upaya perlindungan dan meningkatkan kualitas hidup masyarakat dan berkoordinasi dengan Dinas Kesehatan kabupaten/kota terhadap peredaran produk industri rumah tangga, karena kewenangan dalam mengambil tindakan adalah tugas dari Pemerintah Daerah dalam hal ini dinas kesehatan. Salah satu tindakan yang dilakukan oleh Dinas Kesehatan adalah mengawasi produksi minuman maupun makanan yang disimpan kurang dari tujuh hari. Untuk melaksanakan struktur organisasi dari Badan Pengawasan Obat Dan Makanan maka dibentuk empat seksi yang saling berkaitan yaitu, seksi pemeriksaan, seksi penyelidikan, seksi sertifikasi, dan layanan informasi konsumen. Dalam pengawasan selama beredarnya suatu produk, BPOM melakukan inspeksi mendadak untuk mengetahui apakah

\footnotetext{
9 I Putu Mahentoro, 2017, Kewenangan Badan Pengawas Obat dan Makanan Terhadap Perda Provinsi Bali Nomor 5 Tahun 2012 Tentang Pengendalian Peredaran Minuman Beralkohol, Jurnal Magister Hukum Udayana, Vol 3. No 3, November 2013 h.3, https://ojs.unud.ac.id/index.php/jmhu/article/view/7290, diakses tanggal 1 Februari 2019.
} 
adanya produk-produk minuman yang beredar tidak memiliki izin edar dan mengandung bahan-bahan berbahaya. Dalam hal ini Jika terdapat minuman tradisional loloh cemcem yang beredar tanpa memiliki izin edar, maka BPOM berkoordinasi dengan dinas kesehatankabupaten/kota untuk tindakkan lebih lanjut dan BPOM dapat menjadi saksi ahli jika produk tersebut menimbulkan kerugian bagi konsumen dan menimbulkan terjadinya sengketa konsumen. (wawancara pada 30 Agustus 2018).

BPOM berperan dalam membina industri maupun importir/distributor secara komprehensif mulai dari pembuatan, peredaran serta distribusi. Badan Pengawasan Obat Dan Makanan melakukan pengawasan penerapan CPMB (Cara Pengolahan Makanan yang Baik) dan pengawasan penerapan CPPOB (Cara Pengolahan Pangan Olahan yang Baik). Pengawasan lain yang dilakukan oleh Badan Pengawasan Obat Dan Makanan dimulai sebelum produk beredar yaitu dengan evaluasi produk pada saat pendaftaran (pre marketing evaluation/product safety evaluation), inspeksi sarana produksi sampai kepada pengawasan produk di peredaran (post marketingsurveillance).

Pemerintah dalam melakukan pengawasan terhadap produk makanan yang berbedar diberi wewenang untuk mengambil tindakan administratif, sesuai dengan yang tercantum dalam Pasal 54 angka (2) Undang-Undang Republik Indonesia Nomor 18 Tahun 2012 tentang Pangan, tindakan administratif yang dimaksud berupa : Peringatan secara tertulis, Larangan mengedarkan untuk sementara waktu dan/atau perintah untuk menarik pangan dari peredaran apabila terhadap resiko tercemarnya pangan atau pangan tidak aman bagi kesehatan 
manusia, Pemusnahan pangan jika terbukti membahayakan kesehatan dan jiwa manusia, Penghentian produk untuk sementara waktu, Pengenaan denda paling tinggi Rp.50.000.000,00 (lima puluh juta rupiah), dan Pencabutan izin produksi atau izin usaha.

\subsubsection{Upaya hukum konsumen dalam hal minuman tradisional loloh cemcem yang tidak memiliki izin edar menimbulkan kerugian?}

Merujuk pada Penjelasan Umum Undang-Undang Nomor 8 Tahun 2009 tentang Perlindungan Konsumen, faktor utama yang menjadi penyebab eksploitasi terhadap konsumen sering terjadi adalah masih rendahnya tingkat kesadaran konsumen akan haknya. Tentunya hal tersebut berkaitan erat dengan rendahnya tingkat pendidikan dari para konsumen. Selain kurangnya tingkat kesadaran konsumen akan hak-hak dan kewajibanya yang terkait dengan tingkat pendidikan yang rendah, pemerintah selaku penentu dalam merumuskan kebijakan publik, pelaksana, sekaligus pengawas atas jalanya peraturan yang telah dibuat sepertinya masih kurang serius dalam menjalankan kewajibannya. Produsen yang mencari keuntungan pun masih membandel dengan menghalalkan segala cara untuk memaksimalkan laba yang diperoleh tanpa memperhatikan undang-undang yang berlaku serta kesehatan konsumennya.

Berdasarkan hasil wawancara dengan Luh Putu Witariati selaku Kepala Bidang Sertifikasi dan Layanan Informasi Konsumen Badan Pengawasan Obat Dan Makanan Provinsi Bali dijelaskan bahwa, upaya yang dilakukan dari Badan Pengawasan Obat Dan Makanan Provinsi Bali berupa pembinaan terhadap produsen saja sedangkan kewenangan dalam mengambil tindakan adalah tugas dari Dinas Kesehatan yang merupakan 
bagian dari kewenangan Pemerintah Daerah. Salah satu tindakan yang dilakukan oleh Dinas Kesehatan adalah mengawasi produksi makanan siap saji yakni makanan yang disimpan kurang dari tujuh hari. Untuk melaksanakan struktur organisasi dari Badan Pengawasan Obat Dan Makanan maka dibentuk empat seksi yang saling berkaitan yaitu, seksi pemeriksaan, seksi penyelidikan, seksi sertifikasi, dan layanan informasi konsumen. (wawancara pada 30 Agustus 2018)

Setiap orang yang dirugikan dapat menggugat pelaku usaha melalui lembaga menyelesaikan sengketa antara konsumen dan pelaku usaha melalui peradilan yang berada di lingkungan peradila umum, penyelesaiian sengketa konsumen dapat ditempuh melalui pengadilan atau di luar pengadilan berdasarkan kesepakatan para pihak yang bersengketa. Penyelesaian sengketa di luar pengadilan diselenggarakan untuk mencapai kesepakatan mengenai bentuk dan besarnya ganti rugi dan/atau mengenai tindakan tertentu yang menjamin tidak akan terjadi kembali kerugian yang diderita konsumen, apabila upaya penyelesaian sengketa konsumen di luar pengadilan tidak berhasil oleh salah satu pihak atau oleh para pihak yang bersengketa, maka ditempuh gugatan melalui pengadilan.

Dalam melindungi konsumen pemerintah juga membentuk Badan Penyelesai Sengketa Konsumen (BPSK) di Daerah Tingkat II yang diatur dalam Pasal 49 UUPK untuk penyelesaian sengketa konsumen dengan cara mediasi, abitrase, atau konsiliasi. ${ }^{10}$

10 Dewa Gde Rudy et. al., Buku Ajar Hukum Perlindungan Konsumen, Fakultas Hukum Universitas Udayana, Denpasar, h. 110. 


\section{PENUTUP}

\subsection{Kesimpulan}

1. Peranan BPOM dalam melindungi konsumen terhadap peredaran minuman tradisional loloh cemcem yaitu BPOM telah menyediakan Uni Layanan Pengaduan Konsumen (selanjutnya disingkat ULPK) Yang mana ULPK mempunyai tugas melayani pengaduan konsumen atas obat, makanan dan minuman, obat tradisional, kosmetik, alat kesehatan, dan Narkotika Psikotropika dan Zat Adiktif (NAPZA), serta bahanbahan yang berbahaya lainnya. BPOM berperan untuk memenuhi keinginan masyarakat salah satunya dengan meningkatkan perannya didalam melindungi masyarakat agar terhindar dari peredaran makanan mengandung bahan berbahaya yang berisiko bagi kesehatan dan juga tidak memenuhi syarat mutu dan manfaat. BPOM melakukan pengawasan penerapan CPMB (Cara Pengolahan Makanan yang Baik) dan pengawasan penerapan CPPOB (Cara Pengolahan Pangan Olahan yang Baik).

2. Upaya hukum yang dapat dilakukan konsumen kepada pelaku usaha untuk menuntut ganti rugi terhadap kerugian yang dialami konsumen melalui peradilan yang berada di lingkungan peradila umum, penyelesaiian sengketa konsumen dapat ditempuh melalui pengadilan atau di luar pengadilan berdasarkan kesepakatan para pihak yang bersengketa. Dalam melindungi konsumen pemerintah juga membentuk Badan Penyelesai Sengketa Konsumen (BPSK) di daerah tingkat II yang diatur dalam Pasal 49 UUPK untuk penyelesaian sengketa konsumen dengan cara mediasi, abitrase, atau konsiliasi. 


\subsection{Saran}

Kepada BPOM hendaknya perlu memberikan sanksi hukum yang tegas dan nyata bagi pelaku usaha yang melakukan pelanggaran terhadap peredaran minuman tradisional loloh cemcem yang tidak memiliki izin edar, dan memberikan edukasi, komunikasi, dan informasi secara intensif berupa sosialisasi yang diperuntukan kepada kelompok masyarakat, baik itu dari segi cara pembuatannya (produksi), Hygiene sanitasi tempat usaha maupun dalam proses pengedarannya, dimana pelaku usaha industri rumah tangga harus menyesuaikan dengan peraturan perundang-undangan yang berlaku. Bagi konsumen seharusnya lebih berhati-hati dan paham terhadap produk yang dikonsumsi agar tidak menimbulkan kerugian bagi dirinya dan mengetahui lembaga-lembaga dan proses dalam melindungi konsumen. 


\section{DAFTAR PUSTAKA}

\section{Buku:}

Faudy, Munir, 2008, Pengantar Hukum Bisnis, Citra Aditya Bakti, Badung, h. 227.

Kristiyanti, Celina Tri Siwi, 2011, Hukum Perlindungan Konsumen, Sinar Grafika, Jakarta.

M. Hadjon, Philipus dan Tatiek Sri Djatmiati, 2005, Argumentasi Hukum, Gadjah Mada University Press, Yogyakarta.

Miru, Ahmadi, 2017, Prinsip-Prinsip Perlindungan Hukum Bagi Konsumen Di Indonesia, ed.1, cet.3, Rajawali Pers, Depok.

Rudy, Dewa Gde et. al., Buku Ajar Hukum Perlindungan Konsumen, Fakultas Hukum Universitas Udayana, Denpasar.

Soekanto, Soerjono, 2012, penganter penelitian hukum, Universitas Indonesia (UI-Press), Jakarta, h.51.

\section{Artikel Jurnal}

Agung Brahmanta, A.A Gde, 2016, "Perlindungan Hukum Bagi Konsumen Dalam Perjanjian Baku Jual Beli Perumahan Dengan Pihak Pengembang di Bali”, Acta Comitas, Vol. 1 No. 02, Oktober 2016, h. 211, https://ojs.unud.ac.id/index.php/ActaComitas/article/vie $\underline{\mathrm{w} / 24953 / 16186}$, diakses tanggal 31 Januari 2019.

Mahentoro, I Putu, 2017, Kewenangan Badan Pengawas Obat dan Makanan Terhadap Perda Provinsi Bali Nomor 5 Tahun 2012 Tentang Pengendalian Peredaran Minuman Beralkohol, Jurnal Magister Hukum Udayana, Vol 3. No 3, November 2013, h.3, https://ojs.unud.ac.id/index.php/jmhu/article/view/7290 , diakses tanggal 31 Januari 2019.

Nurhayati, Irna, 2009, "Efektifitas Pengawasan Badan Pengawas Obat dan Makanan Terhadap Peredaran Produk Pangan Olahan Impor Dalam Mewujudkan Perlindungan Konsumen”, Jurnal Ilmiah, Vol 21 nomor 2, Juni 2009, h. 17, https://jurnal.ugm.ac.id/jmh/article/view/16265, diakses tanggal 31 Januari 2019. 


\section{Perundang-undangan}

Indonesia, Undang-Undang Tentang Perlindungan Konsumen, Undang-Undang Nomor 8 Tahun 1999 Lembaran Negara Republik Indonesia Tahun 1999 Nomor 42 Tambahan Lembaran Negara Republik Indonesia Nomor 3821.

Peraturan Daerah Kabupaten Tabanan Nomor 9 Tahun 2014 tentang Perizinan Bidang Kesehatan (Lembaran Daerah Kabupaten Tabanan Nomor 9 Tahun 2014, Tambahan Lembaran Daerah Kabupaten Tabanan Nomer 9).

Peraturan Pemerintah Republik Indonesi Nomor 28 Thahu 2004 tentang Keamanan, Mutu, dan Gizi Pangan (Lembaran Negara Republik Indonesia Nomor 107 Tahun 2004, Tambahan Lembaran Negara Republik Indonesia Nomor 4424).

Peraturan Presiden Republik Indonesia Nomor 80 Tahun 2017 tentang Badan Pengawas Obat dan Makanan (Lembaran Negara Republik Indonesia Nomor 180 Tahun 2017).

\section{Internet}

Badan Pengawas Obat dan Makanan, 2013, "Latar Belakang Badan Pengawas Obat dan Makanan", URL: https://www.pom.go.id/new/view/direct/background diakses tanggal 7 Oktober 2018. 